\title{
Rancangan Teknologi Tepat Guna untuk Mesin Penggiling Kopi Sistim Poros Vertikal
}

\author{
Appropriate Technology Design For Grinder Machine Coffee \\ Vertical Poros System
}

\author{
Alfian \\ Jurusan Teknik Mesin Politeknik Negeri Padang Kampus Limau Manis Padang \\ Telp. 0751-72590 Fax. 0751-72576 Email: alfian_sofjan@yahoo.co.id
}

\begin{abstract}
Coffee is material of drink and coffee income for Indonesia Country. Each one of coffee proses for drink is grind proses. Grind coffee proses influence of taste and confortable. The grind coffee prosesto produce powder, natural aroma, big capacity, easily found, estetika, and economic value.

From research, hoper the grind coffee machine is the produce coffee powder, natural aroma, capacity, small power electrical, portable, estetika and economic value.

In this paper Grinder Coffee Machine Vertical Shaft System, to produce grinder with Conical Burr Grinder so natural aroma, powder smoot and same size. The specification this machine is power 0.5 HP, motor rotation $500 \mathrm{rpm}$, size $300 \mathrm{~mm} \times 300 \mathrm{~mm} \times 470 \mathrm{~mm}$ and capacity produce $106 \mathrm{~kg} / \mathrm{hour}$.
\end{abstract}

Keywords: Coffee Powder, Coffee Grinders, Vertical Shaft, Conical Grinder, Grinding Machine

\section{PENDAHULUAN}

Kopi adalah hasil bumi yang sudah lama dipakai manusia untuk minuman baik untuk minum di pagi hari ataupun untuk begadang di malam hari. Sebahagian besar manusia di dunia ini adalah penikmat kopi sehingga, kopi sudah menjadi barang komoditi dibeberapa negara penghasil kopi termasuk negara Indonesia. Kopi Indonesia saat ini ditilik dari hasilnya, menempati peringkat ke empat terbesar di dunia. Perolehan devisa ekspor khususnya untuk komoditas kopi (kopi biji ekstrak, roasted) dan kelapa tahun 2000, masing-masing sebesar 339,88 juta US\$ dan 396,15 juta US\$. [1].

Produksi kopi di Indonesia saat ini mencapai 600.000 ton/tahun. Lebih dari $80 \%$ produksi tersebut berasal dari perkebunan rakyat. Perkebunan ini merupakan kumpulan dari kebun-kebun kecil yang dimiliki petani dengan luasan 1 2 ha. Mereka tidak mempunyai modal, teknologi, dan pengetahuan yang cukup untuk mengelola tanaman yang mereka miliki secara optimal. [2]
Salah satu jenis kopi yang terdapat di Indonesia dimana, sudah melalui proses pengolahan dan siap untuk digiling seperti gambar 1 di bawah ini :

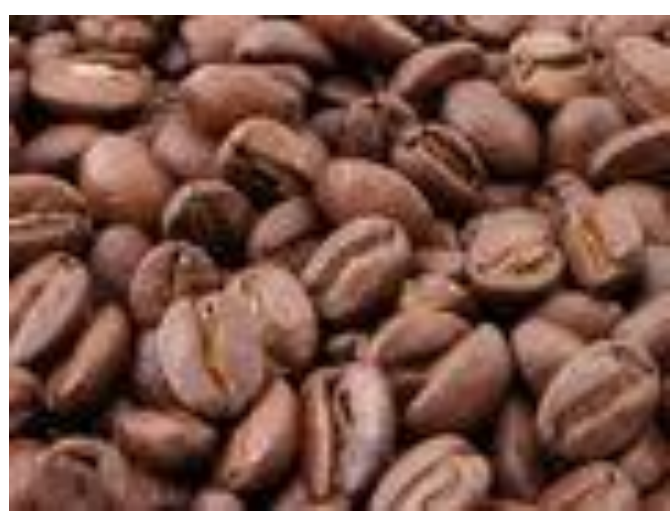

Gambar 1. Biji Kopi Siap Untuk Digiling

Proses yang dilalui biji kopi sebelum proses penggilingan untuk menjadi bubuk kopi yang siap diseduh atau disajikan adalah

Panen kopi matang (berwarna hitam) di kebun. Pemilihan buah kopi dalam bak (air) sipon. Pengupasan buah kopi

Pengeringan buah kopi yang sudah dikupas (biji kopi). Pemilihan biji kopi sesuai 
dengan tingkat ukuran. [4] Semua proses dilakukan dengan cara tradisional dan sangat berhubungan dengan kondisi alam pada saat kopi dipanen. Sebelum biji Kopi ditumbuk atau digiling terlebih dahulu melalui proses penggorengan. Proses penggorengan yang baik akan menghasilkan Kopi yang tahan lama serta bubuk kopi yang halus dan nikmat.

Para perajin Kopi (pengolah bubuk kopi) skala industri rumah tangga, rata - rata membutuhkan 5 - 50 kilogram biji kopi sehari. Biji kopi tersebut kemudian di olah menjadi bubuk kopi. Kopi tersebut dikemas dalam berbagai ukuran kantong dengan harga jual Rp 25.000 - Rp 30.000 per kilogram. [5]

Di negara Indonesia sekarang banyak bermunculan merk kopi yang siap dihidangkan, tetapi bagi penikmat kopi tidak merasa puas karena rasa kopinya yang sudah bercampur. Penikmat kopi masih selalu mencari produk kopi yang dihaluskan secara tradisional, seperti ditumbuk, digiling dengan batu, digiling menggunakan mesin secara horizontal dengan bantuan screw dan lain - lain. Hasil dari penggilingan mesin - mesin di atas ada mempunyai kelemahan - kelemahan antara lain : Pada mesin penggiling horizontal dengan bantuan screw, bodinya yang besar sehingga susah untuk dibawa ,hasil penggilingan yang tidak sama besar dan tidak halus, mempunyai daya yang cukup besar sehingga untuk pemakaian terbatas.

Berdasarkan keterangan di atas penulis mencoba merancang mesin penggiling kopi dengan sistim poros vertical, dimana mesin tersebut dapat digunakan dengan mudah, memanfaatkan gaya berat biji kopi untuk masuk ke dalam piringan penggiling kopi, mudah dibawa (portable), menggunakan daya yang kecil sehingga dapat digunakan dalam rumah tangga, dan biaya perawatan yang rendah serta mempunyai nilai estetika yang tinggi sehingga mesin tersebut dapat diletakkan, dipergunakan pada tempat tempat yang eksklusif.

\section{METODOLOGI}

\section{Proses Penggilingan Biji Kopi}

Mesin penggiling menggunakan putaran untuk menghancurkan dan menghaluskan biji kopi dengan, membuat mata penghancur disekeliling piringan penggiling. Sistim penggilingan yang tertutup dapat mempertahankan aroma yang dimiliki kopi. Kecepatan putar piringan penggilingan kurang dari 500 rpm guna mendapatkan hasil penggilingan biji kopi yang halus. [3]

Mesin penggiling kopi yang dipakai pada kebanyakan tempat industri penghasil kopi serta penggunaan pada penjual kopi adalah mesin penggiling dengan sistim kerja pada posisi horizontal. Proses penggilingan dapat ditunjukan pada gambar 2 di bawah ini :

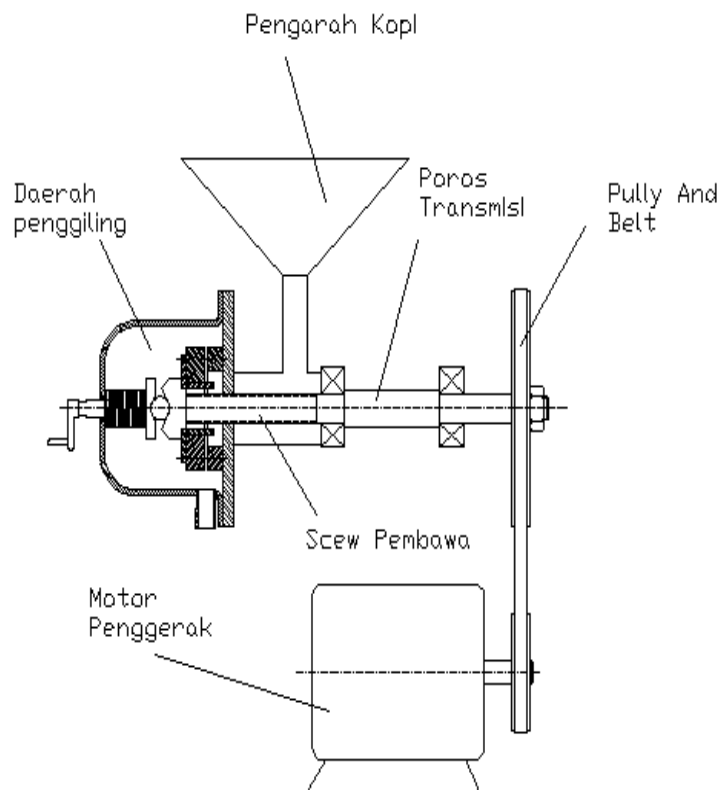

Gambar 2. Mesin Penggiling Biji Kopi

Horizontal Dengan screw

Pada gambar di atas terlihat proses perlakuan penggilingan biji kopi diawali dari corong masuk yang memanfaatkan gaya berat sehingga biji kopi turun ke bawah menuju srew pembawa. Screw pembawa berputar dengan dihubungkan dengan motor penggerak lalu kemudian biji kopi dialirkan ke dalam daerah penggilingan. Pada daerah penggilingan 
proses pemecahan dan penghalusan biji kopi terjadi sampai digiling halus dan menghasilkan bubuk kopi yang siap untuk diseduh.

Mesin penggiling kopi terdiri atas beberapa bagian utama seperti yang terlihat pada Gambar 1. Ada empat bagian utama yang memegang peranan penting yaitu pengarah kopi, daerah penggiling, poros transmisi dan motor penggerak. Pengarah kopi adalah tempat masuk biji kopi yang akan digiling. Daerah penggiling adalah tempat biji kopi diproses dari ukuran awal menjadi ukuran yang lebih kecil sesuai dengan ukuran yang diinginkan. Poros transmisi yaitu pengatur kecepatan putar pada waktu proses penggilingan, motor penggerak adalah sumber pemutar dari poros. Mesin penggiling biji kopi dengan cara sistim horizontal membutuhkan tempat yang besar dan luas karena konstruksinya yang terpisah antara alat pengiling dengan motor penggerak. Pada daerah penggilingan masih mempergunakan batu air sebagai alat penghancur yang terpasang dengan saling berhadapan pada pasisi kiri dan kanan.

Berdasarkan informasi di atas penulis mencoba untuk membuat sesuatu rancangan yang baru supaya kendala yang ditemukan pada mesin penggiling biji kopi dengan sistim horizontal dapat diperkecil. Ada beberapa langkah yang dilakukan untuk mendapatkan solusi dari kekurangan dari mesin dengan sistim horizontal anatara lain adalah sebagai berikut .

\section{Pilihan Rancangan}

Setiap perancangan diawali dengan permasalahan yang ada sebagai pekerjaan yang harus diselesaikan. Beberapa pertimbangan umum untuk membuat sebuah rancangan antara lain : tempat, ketersediaan bahan baku, peralatan, jarak, biaya, estetika dan yang paling utama yaitu dapat mempertahankan aroma serta kualitas bubuk kopi yang dihasilkan setelah dilakukan proses penggilingan. Selain pertimbangan umum di atas yang sangat perlu diperhatikan dari rancangan mesin penggiling biji kopi yang akan dibuat adalah spesifikasi teknis dalam perancangan mesin yang akan dibuat adalah, ukuran bubuk kopi dari hasil penggilingan, penggunaan tenaga penggerak, pemilihan material yang akan digunakan, mudah dioperasikan, kapasitas produksi, ergonomis, k3 dan ekonomis. Untuk menghasilkan keputusan yang maksimal ada beberapa hal yang diperhatikan sehingga, membutuhkan pertimbangan - pertimbangan yang matang dan akurat. Faktor - faktor yang mempengaruhi keputusan alternatif adalah, alternatif keteknikan yang dapat dirancang serta design yang dapat diproduksi atau dibuat di bengkel-bengkel produksi. Metode pembuatan mesin dengan mensingkron dengan peralatan pemesinan yang dapat dikerjakan. Metode perakitan dengan melakukan kemudahan dalam asembly baik secara langsung ataupun dengan cara bongkar pasang. Biaya pembuatan ditekan serendah mungkin sehingga harga dapt ditekan dan terjangkau, dan perawatan mesin dapat dilakukan dengan mudah dan bertahan lama.

Membuat perbandingan antara mesin yang sudah ada dengan beberapa alternatif yang akan dirancang dan dibuat. Alternatif pemilihan sistem penggilingan selain dari gambar 1 adalah pada gambar 3 dan gambar 4.

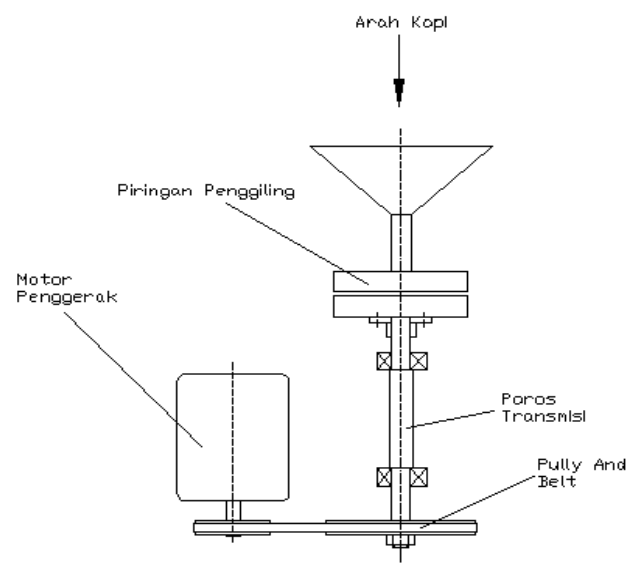

Gambar 3. Penggilingan Vertikal Dengan pully 


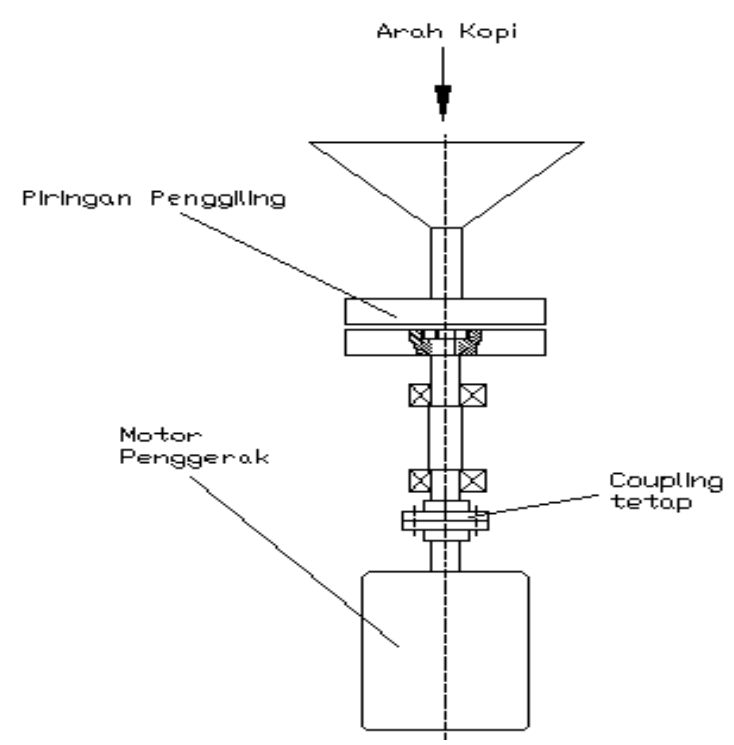

Gambar 4. Penggilingan vertikal Dengan Transmisi Langsung Dari Motor

Dalam menentukan hasil sebuah keputusan yang akan diambil dari sebuah kasus perbandingan antara beberapa pilihan yang harus dipilih maka, dibutuhkan ketetapan analisa alternatif yang dituangkan dalam bentuk jenis dari sistim yang akan dibuat, kelemahan serta kelebihan sehingga, dapat dinyatakan sebuah produk itu lebih unggul dari pembanding yang lain.

Pada tiga rancangan di atas perlu adanya analisa alternatif tentang jenis sitim pemotongan yanga akan dibuat dimana, analisa ini berhubungan dengan besar atau kecil mesin yang akan dibuat sehingga, sangat berpengaruh pada tempat atau ukuran mesin yang akan dibuat. Kelebihan yang akan didapatkan dari alat yang akan dibuat adalah sebuah analisa alternatif untuk, mengetahui seberapa keunggulan kinerja, konstruksi dan dimensi dari mesin dalam melakukan proses penggilingan biji kopi. Analisa alternatif kelemahan dari sebuah produk yang akan melakukan proses penggiling biji kopi dimana, dari bahan ukuran besar menjadi kecil hingga dihasilkan dalam bentuk bubuk dengan butiran yang sangat kecil seperti tepung.

Berdasar yang diperlihatkan pada Tabel 1 maka dapat disimpulkan rancangan dan design yang cocok untuk penggiling yang akan dibuat adalah yang memenuhi kriteria dan syarat yang sudah ditentukan.

\section{HASIL DAN PEMBAHASAN}

\section{Rancangan Teknologi Tepat Guna Penggiling Kopi yang Terpilih}

Rancangan yang ditawarkan sebagai solusi alternatif teknologi tepat guna penggilingan kopi yang dapat menggantikan alat yang ada, dari beberapa analisa yang terdiri dari jenis sisitim pemotongan, kelemahan dan kelebihan. Hal ini dirasa cocok dengan kondisi perkebunan skala kecil yang banyak terdapat di Indonesia dimana, sangat dibutuhkan mesin penggiling kopi yang menghasilkan bubuk kopi, mudah dibawa dan ekonomis. 
Tabel 1. Analisa alternatif

\begin{tabular}{|c|c|c|c|}
\hline No & $\begin{array}{l}\text { Jenis sistim } \\
\text { Pemotongan }\end{array}$ & $\begin{array}{l}\text { Kelemah- } \\
\text { an }\end{array}$ & $\begin{array}{l}\text { Kelebih- } \\
\text { an }\end{array}$ \\
\hline 1 & $\begin{array}{l}\text { Penggilingan } \\
\text { Horizontal }\end{array}$ & $\begin{array}{l}\text { 1. Biji } \\
\text { kopi } \\
\text { didorong } \\
\text { oleh } \\
\text { screw } \\
\text { untuk } \\
\text { masuk ke } \\
\text { dalam } \\
\text { piringan } \\
\text { penggilin } \\
\text { g } \\
\text { 2. Hasil } \\
\text { penggilin } \\
\text { gan kasar. }\end{array}$ & $\begin{array}{l}\text { Panas } \\
\text { yang } \\
\text { ditimbulk } \\
\text { an saat } \\
\text { penggilin } \\
\text { gan } \\
\text { leratif } \\
\text { lebih } \\
\text { rendah }\end{array}$ \\
\hline 2 & $\begin{array}{l}\text { Penggilingan } \\
\text { Vertikal } \\
\text { Dengan pully }\end{array}$ & $\begin{array}{l}\text { 1. Kontru } \\
\text { ksi } \\
\text { transmisi } \\
\text { agak } \\
\text { rumit } \\
\text { 2. Dimen } \\
\text { si relatif } \\
\text { lebih } \\
\text { lebar }\end{array}$ & $\begin{array}{l}\text { 1. Kecep } \\
\text { atan } \\
\text { putar } \\
\text { dapat } \\
\text { diatur. } \\
\text { 2. Motor } \\
\text { listrik } \\
\text { dapat } \\
\text { divariasi } \\
\text { kan } \\
\text { karena } \\
\text { lebar. }\end{array}$ \\
\hline 3 & $\begin{array}{l}\text { Penggilingan } \\
\text { Vertikal } \\
\text { Dengan } \\
\text { Transmisi } \\
\text { Langsung } \\
\text { Dari Motor }\end{array}$ & $\begin{array}{l}\text { 1. Konstr } \\
\text { uksi } \\
\text { mesin } \\
\text { sederhana } \\
\text { 2. Dimen } \\
\text { si lebih } \\
\text { kecil }\end{array}$ & $\begin{array}{l}\text { 1. Keteb } \\
\text { alan } \\
\text { bubuk } \\
\text { kopi } \\
\text { dapat } \\
\text { diatur. } \\
\text { 2. Portab } \\
\text { le }\end{array}$ \\
\hline
\end{tabular}

Hal di atas dapat ditemukan pada rancangan teknologi tepat guna mesin penggiling kopi sistim poros vertikal yang ditunjukan pada gambar 6 .

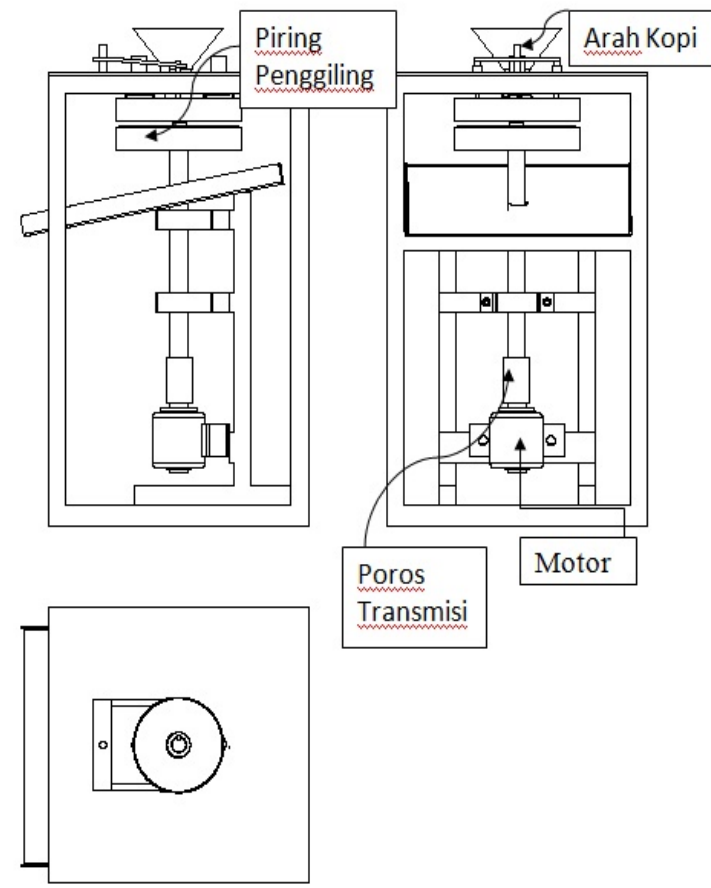

Gambar 5. Rancangan mesin penggiling kopi vertikal

Terdapat empat komponen utama dari desain rancangan yang dibuat yaitu pengarah masuknya kopi, piringan penggilingan yang terdiri dari piringan atas dan bawah, poros transmisi yang berfungsi sebagai penerus putaran dan motor sebagai sumber putaran. Motor dan pengarah dapat disediakan setelah dilakukan asembly sedangkan piring penggiling dan poros harus dirancang dan dikalkulasi dengan cermat. Untuk membuat rancangan dan kalkulasi dibutuhkan beberapa metode serta alat bantu guna menghasilkan sebuah produk yang menghasilkan unjuk kerja serta kinerja yang mumpuni. Metode dapat kita lakukan dengan mengadop dari beberapa referensi seperti buku dan tulisan orang lain.

Rancangan daerah piring penggiling biji kopi dibuat dengan aplikasi CATIA dengan membuat gambar 3 dimensi dan 2 dimensi serta dalam bentuk simulasi yang ditunjukan pada gambar 6 dan gambar 7 di bawah ini : 


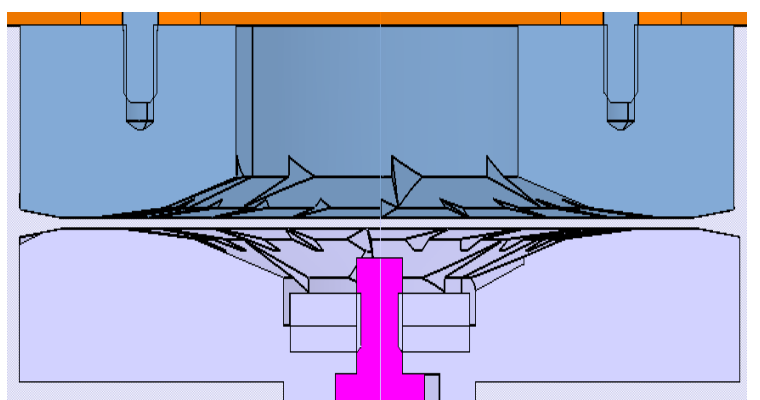

Gambar 6. Daerah piring penggiling kopi

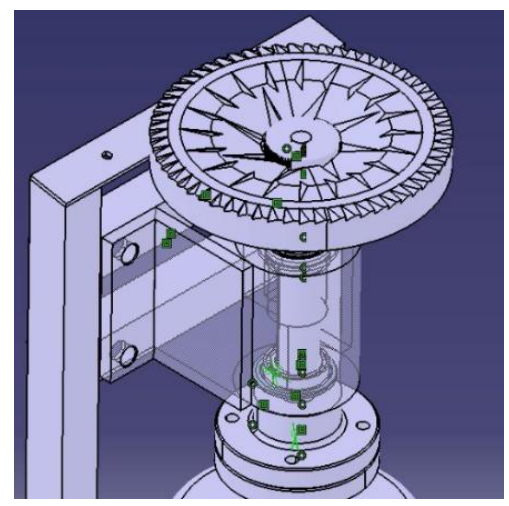

Gambar 7. Asembly piring penggiling bawah

Pada daerah penggiling kopi hasil rancangan yang telah dibuat terdapat piringan yang berfungsi sebagai pemotong dan landasan sehingga, terjadi proses pemecahan biji kopi secara bertahap. Tahapan pemecahan dimulai dari butiran besar kemudian hasil pemecahan dialirkan keproses yang lebih kecil sampai dengan 3 tahapan yang akan menghasilkan butiran yang sangat kecil. Setelah proses tahapan pemecahan dilalui hingga butiran yang sangat kecil lalu, dilanjutkan dengan proses penghalusan untuk mendapatkan hasil menjadi bubuk kopi yang siap untuk di seduh dan dinikmati.

Semua proses yang dilakukan di atas tersebut terangkum dalam sebuah piringan yang yang berbentuk bulat, mempunyai sudut potong serta kemiringan guna mendistribusikan hasil perlakuan yang terjadi pada setiap tahapan kerja satuannya. Bentuk rancangan piringan tersebut terdiri dari piringan yang berada pada bahagian atas mesin yang berfungsi sebagai landasan terpasang rigid pada dudukan. Selanjutnya piringan yang berfungsi sebagai pisau atau pemecah dipasang pada poros yang terhubung pada motor penggerak yang berputar sehingga, piringan berputar untuk melakukan penyayatan, penggilingan serta proses penghalusan biji kopi sampai menjadi bubuk atau tepung. Bentuk rancangan dari piringan penggiling biji kopi tersebut ditunjukan pada gambar 8 dan gambar 9 di bawah ini :

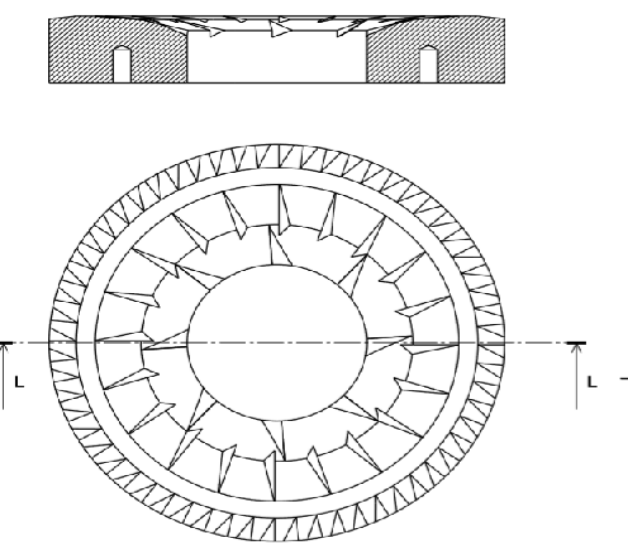

Gambar 8. Piringan penggiling atas

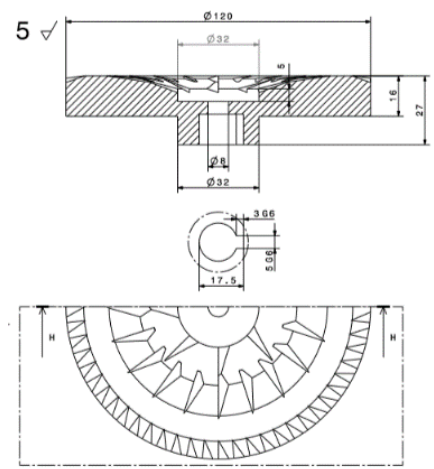

Gambar 9. Piringan penggiling bawah

Pada proses rancangan selanjutnya adalah memprediksi hasil dari proses kerja dari piringan atas dengan piringan bawah pada waktu bekerja melakukan pemecahan, penggilingan serta menghaluskan biji kopi yang sudah berada pada daerah penggilingan. Aliran penggilingan biji kopi yang dihasilkan dari hasil penggorengan sesuai dengan standar dimana bahan memenuhi syarat untuk dilakukan proses menjadi bubuk kopi yang siap diseduh.

Rancangan proses pemecahan biji kopi adalah langkah pertama yang dilakukan pada mata pisau yang terdapat pada piringan dimana, sudut potongnya dibuat besar sesuai dengan ukuran bahan 
yang akan di proses. Mata pisau yang dibuat adalah disekeliling piringan sebanyak 8 dengan panjang tertentu. Perlakuan ini terdapat pada daerah tengah dari piringan penggiling dimana proses ini disebut dengan tahapan satu yaitu proses pemecahan biji kopi. Pada proses 1 yang terjadi adalah biji kopi pecah dengan ukuran yang bervariasi sehingga pada pisau dibutuhkan tempat pengumpul serta distribusi aliran ketempat pemecahan berikutnya. Proses di atas ditunjukan pada gambar 10

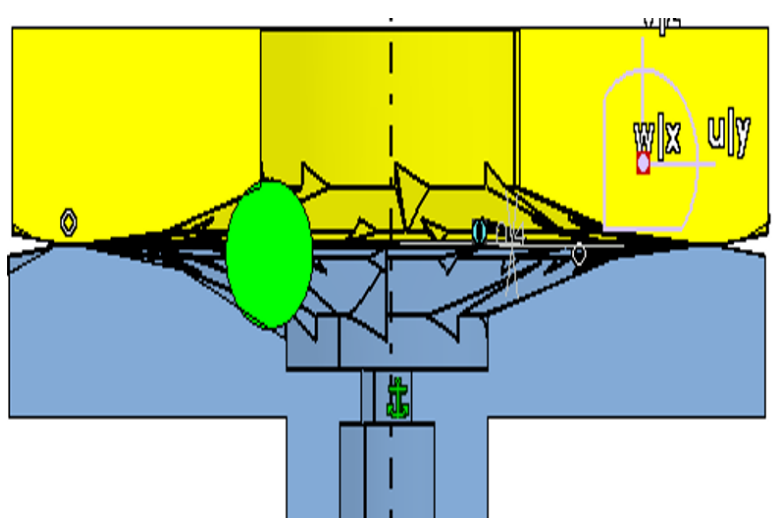

Gambar 10. Tahapan ke satu

Rancangan proses penggilingan pada proses berikutnya disebut dengan tahapan ke dua. Mata pisau dibuat lebih kecil serta kedalaman yang semakin dangkal karena, material pecahan biji kopi sudah semakin kecil. Pada tahapan ke dua ini terjadi di 2 tempat yaitu

1. Diantara mata pisau tahapan satu

2. Sejajar dengan pisau tahapan satu Hasil pemecahan yang terjadi pada tahapan satu diteruskan menuju tahapan ke 2 dimana, pada areal tersebut terjadi proses pemecahan yang semakin kecil untuk menghasilkan kehalusan kopi yang diinginkan. Adapun hasil pemecahan dari tahapan satu keluar butiran yang kecil terdapat juga hasil yang sudah sangat kecil, untuk bahan ini bisa langsung dialirkan untuk proses selanjutnya. Proses tahapan ke dua ini dapat disimulasikan dengan aplikasi CATIA yang digunakan dimana, dari proses ke satu dilanjutkan ke proses berikutnya, seperti yang ditampilkan pada gambar 11 di bawah ini :
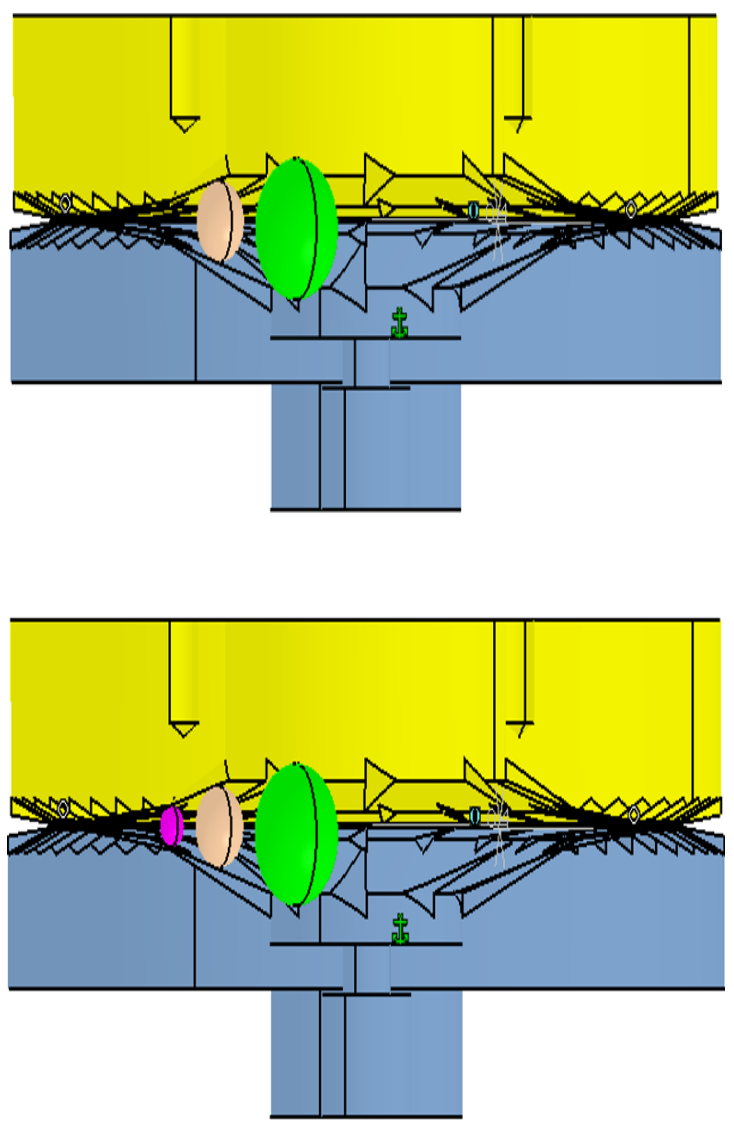

Gambar 11. Tahapan ke dua

Pada proses akhir biji kopi menjadi bubuk kopi dimana, biji kopi yang sudah melalui proses pemecahan hingga menjadi sangat kecil digiling atau digesek dengan, merapatkan piringan bawah dengan yang di atas sehingga, bahan menjadi bubuk dan keluar melalui ujung pinggir dari kedua piringan penggiling tersebut. Pada gambar 12 ditunjukan proses perjalanan biji kopi dari awal besar lalu mengecil dan mengecil lagi dengan proses penggilingan dari mata pisau yang terdapat pada piringan. Kemudian bahagian yang sangat kecil tersebut digesek lagi dengan permukaan piringan sehingga, menghasilkan material seperti bubuk kopi yang siap untuk diseduh pada pagi hari. Untuk menghasilkan kualitas penggilingan yang maksimal hendaknya hasil bubuk kopi diayak terlebih dahulu dengan mesh yang sudah ditentukan sehingga, terdapat kesamaan pada produk bubuk kopi yang dihasilkan. 


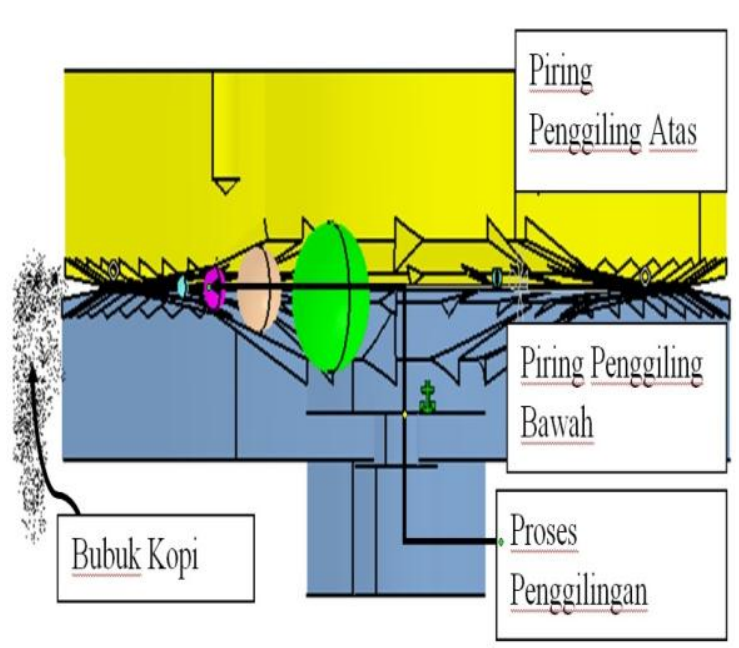

Gambar 12. Proses penggilingan di dalam piringan

Dibutuhkan gaya untuk menghancurkan biji kopi hingga menjadi bubuk kopi melalui proses pengujian. Beberapa tahapan pengujian biji kopi yang akan digiling yaitu 1) berat, 2) gaya tekan sampai pecah dan 3) dimensi. Pengujian dilakukan di laboratorium dengan mempergunakan 1) timbangan dan jangka sorong dimana hasil pengujiaan ditunjuk di bawah ini :

1. Panjang (p): $11,437 \mathrm{~mm}$

2. Lebar (l) : $8,225 \mathrm{~mm}$

3. Tinggi $(\mathrm{t}): 5,016 \mathrm{~mm}$

4. Luas (A) : pxl $=94.069 \mathrm{~mm}^{2}$

5. Volume (v): 475,659 $\mathrm{mm}^{3}$

6. Massa (m) : $0.1875 \times 10^{-3} \mathrm{Kg}$

7. Massa jenis kopi

$$
\left(\rho_{\text {kopi }}\right) \quad \frac{m}{v} \quad: 3,942 \times 10^{-7}
$$

$\mathrm{kg} / \mathrm{mm}^{3}$

8. Gaya tekan rata - rata

$$
\left(F_{\text {tekan }}\right) \quad: 2,2917=2,3 \mathrm{Kg}
$$

9. Tegangan tekan

$$
\begin{aligned}
\left(\sigma_{t}\right) \quad \frac{F}{A}= & 0.064 \\
& K g / \mathrm{mm}^{2}
\end{aligned}
$$

10. Tegangan geser

$$
\left(\tau_{\text {kopi }}\right) \quad 0,6\left(\sigma_{t}\right)=0.038 \mathrm{Kg} / \mathrm{mm}^{2}
$$

Dari hasil percobaan ini didapat gaya yang digunakan untuk menggiling bahan baku tersebut sebesar $6 \mathrm{~kg}$. Dengan alasan kemungkinan keakuratan dari timbangan dan factor lain pada konstruksi nantinya maka untuk perencanaan gaya pemecahan yang akan di jadikan dasar perhitungan selanjutnya dibuat factor pengali sebesar 1,5. maka diperoleh gaya pemecahan sebagai berikut :

$$
\left(F_{\text {tekan }}\right)=1,5 \times 6=9 \mathrm{Kg} .
$$

Hal ini juga mempertimbangan keadaan terburuk, baik dari piringan untuk memecahkan maupun kondisi bahan baku yang akan digiling. Dengan demikian persamaan diperoleh:

$$
\begin{aligned}
& \mathrm{F}=\mathrm{m} . \mathrm{g} \\
& \mathrm{g}=\text { Percepatan gravitasi }=9,81 \mathrm{~m} / \mathrm{s}^{2} \\
& \mathrm{~F}=9 \mathrm{Kg} \times 9,81 \mathrm{~m} / \mathrm{s}^{2}=88,29 \mathrm{Kg} \\
& \mathrm{m} / \mathrm{s}^{2} \quad=88,29 \mathrm{~N} \mathrm{~F}
\end{aligned}
$$

\section{Penentuan Kapasitas $(Q)$ Penggiling Biji Kopi Selama Satu Jam}

Dalam membuat rancangan mesin penggiling kopi ini penulis mengambil kecepatan putar piringan (n) $500 \mathrm{rpm}$ [9] dan piringan penggiling dengan diameter $(\phi) 120 \mathrm{~mm}$.

Jadi kapasitas (Q) biji kopi yang diinginkan jika proses penggilingan tersebut dikerjakan selama satu jam :

Kecepatan sudut putaran

$$
\omega=\frac{2 . \pi \cdot n}{60}=\frac{2 \times 3,14 \times 500}{60}=52,36 \mathrm{rad} / \mathrm{s}
$$

Kecepatan piringan penggiling kopi

$$
v=\omega \cdot r=52,36 \times 0,06=3,14 \mathrm{~m} / \mathrm{s}
$$

Waktu bubuk kopi sampai di ujung piringan penggiling 


$$
t=\frac{r}{v}=\frac{0,06}{3,14}=0,02 \mathrm{~s}
$$

Volume dari mata pisau piringan penggiling Untuk satu mata pisau :

$\mathrm{V}=\frac{1}{2}$ alas $\times$ tinggi $\times$ panjang

$$
=1 / 2 \times 5 \times 3 \times 10=75 \mathrm{~mm}^{3}
$$

Total mata pisau 20 buah :

$$
\begin{aligned}
V_{\text {total }}=20 & \times V \\
& =20 \times 75=1500 \mathrm{~mm}^{3}
\end{aligned}
$$

Kapasitas $(Q)$ mesin penggiling kopi

$$
\begin{aligned}
& (Q)=\frac{V_{\text {total }} \cdot \rho}{t}= \\
& \frac{1500 \times 3,942 \times 10^{-7}}{0,02}=0,0296 \mathrm{Kg} / \mathrm{s} \\
& =0,0296 \mathrm{Kg} / \mathrm{s} \times 3600 \\
& =106,434 \mathrm{Kg} / \mathrm{jam}
\end{aligned}
$$

\section{Penentuan Daya Motor}

Sebelum mencari daya motor terlebih dahulu akan mencari daya mesin akibat penggilingan :

$$
\begin{array}{cc} 
& \mathrm{P}=\mathrm{T} \times \mathrm{x} \omega \\
\text { Dimana }: & \mathrm{T}=\text { Torsi }=\mathrm{F} \times 1
\end{array}
$$

Dan 1 adalah jarak gaya penggilingan terhadap pusat poros seperti yang di tunjukkan pada gambar di bawah ini maka :

$\mathrm{T}=88,29 \mathrm{~N} \times 30 \mathrm{~mm}=2648,7 \mathrm{Nmm}$

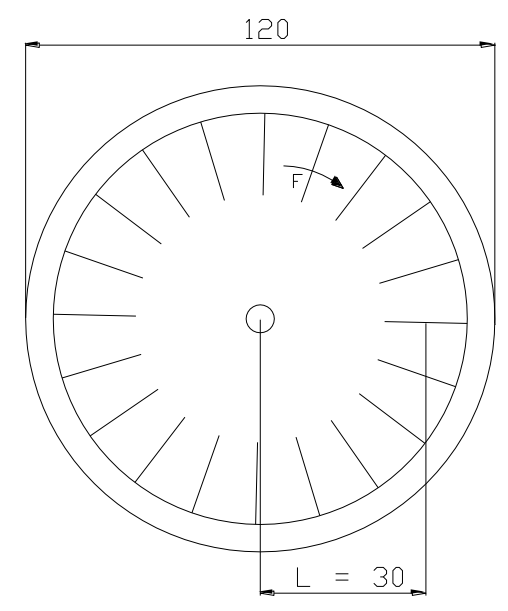

Gambar 13. Dimensi piringan pisau penggiling

maka :

$\mathrm{P}=\mathrm{T} \times \omega=2648,7 \times 52,36=138685,93$

$\mathrm{Nmm} / \mathrm{s}=138,69 \mathrm{Nm} / \mathrm{s}$

Untuk mencari daya motor (Pm) perlu adanya efisiensi rugi-rugi mesin, karena pada saat penggilingan maka beban yang diterima oleh motor akan besar sehingga dibutuhkan efisiensi mekanis $(\eta)$ guna mendapatkan daya rata-rata yang akan diperlukan, dalam perencanaan mesin penggiling kopi ini penulis mengambil efisiensi mekanis $(\eta)=0,6$ Maka daya motor didapat :

$$
\begin{aligned}
& \mathrm{Pm}=\frac{P}{\eta}=\frac{138,69}{0,6}=231,15 \mathrm{~N} \cdot \mathrm{m} / \mathrm{s} \\
& \mathrm{Pm}=231,15 \text { watt } \\
& \mathrm{Pm}=0,231 \mathrm{Kwatt} \\
& \mathrm{Pm}=\frac{231,15}{736}=0,31 \mathrm{HP}
\end{aligned}
$$

Daya motor yang ada dipasaran diambil 0,5 $\mathrm{HP}=368$ watt $=0,368 \mathrm{Kwatt}$

Dengan putaran $500 \mathrm{rpm}$

Dari data daya motor tersebut didapat daya rencana untuk menentukan proses perhitungan selanjutnya. Dimana daya rencana yang akan diteruskan dikalikan dengan factor koreksi agar konstruksi lebih aman. 
didapat $\mathrm{fc}=1,3$

$$
\begin{aligned}
\text { Maka : } \quad \mathrm{Pd} & =\mathrm{Pm} \times \mathrm{fc} \\
& =0,368 \times 1,3=0.48 \\
\mathrm{Kw}=0 & , 48 \mathrm{KNm} / \mathrm{s}
\end{aligned}
$$

Sehingga torsi sesungguhnya :

$$
\begin{aligned}
& \mathrm{T}=\frac{P d}{\omega}=\frac{0.48 \mathrm{KNm} / \mathrm{s}}{52,36 \mathrm{rad} / \mathrm{s}} \\
& \mathrm{T}=0.0091 \mathrm{KNm}=9100 \mathrm{Nmm} \\
& \mathrm{T}=\frac{9100}{9,81}=927,63 \mathrm{~kg} \mathrm{~mm}
\end{aligned}
$$

\section{SIMPULAN}

Telah dirancang suatu alat teknologi tepat guna untuk mesin penggiling kopi sistim poros vertikal yang, menghasilkan bubuk kopi yang halus, mempunyai estetika serta bernilai ekonomis. Konsep disain yang dipakai dalam merancang mesin penggiling kopi ini adalah bahwa, alat ini dapat 1) mereduksi biji kopi, 2) menjamin aroma kopi, 3) menjamin ketebalan hasil penggilingan bubuk kopi, 4) konstruksi yang sederhana, 5) mengintegrasikan aspek ergonomi dan 6) biaya yang murah. Spesifikasi teknis dari mesin penggiling kopi sistim poros vertikal adalah, 1) daya motor yang digunakan $0,5 \mathrm{HP}, 2$ ) putaran motor $500 \mathrm{rpm}, 3)$ dimensi dari mesin panjang $300 \mathrm{~mm} \times$ lebar $300 \mathrm{~mm} \times$ tinggi 470 mm dan 4) kapasitas 106 kg/jam.

\section{DAFTAR PUSTAKA}

Dwi Pamuji Sulistyanto. Jumat, 01 April 2005. Andalkan Kopi dan Teh Murni. Semarang: Suara Merdeka

Satryani Kartika Ningrum. Rabu, 18 Januari. 2006. Mantapnya Rasa Kopi Jetak. Muria : Suara Merdeka.
Bueche, Frederick J. 1992. Teori dan Soal - soal Fisika, Seri Buku Schaum. Jakarta : Erlangga.

Ir. Sularso. MS ME, Kiyokatsu Suga. 1997. Dasar Perencanaan dan Pemilihan Elemen Mesin. PT Pradnya Paramita, Jakarta

Ir. Moch. Zein Nasution, Ir. Srie Setiahartini. 1978. Pengolahan Hasil Pertanian 1. Departemen Pendidikan dan Kebudayaan : Direktorat Pendidikan Menengah Kejuruan.

Prof.Ir. Abdul Kadir. 1 982. Mesin Tak Serempak. Djambatan, Jakarta

Takeshi, Shato and Sugiharto H. 1999. Menggambar Mesin Menurut ISO. PT Pradnya Paramita, Jakarta 